\title{
Constitutionalizing (In)justice: Treaty Interpretation and the Containment of Indigenous Governance
}

\author{
Gina Starblanket ${ }^{\star}$
}

\section{Introduction}

To state that the Canadian criminal justice system has historically failed to provide adequate measures of justice for Indigenous peoples would be both an understatement and a mischaracterization. Canadian institutions of justice have not merely failed Indigenous peoples but were not designed to protect Indigenous interests to begin with. Designed by and for European newcomers who sought to institute their own legal orders, the justice system has functioned as an integral part of the structure of settler colonialism in Canada. As the institutional relationship between Indigenous, federal, and provincial governments has never been reconfigured in such a way that represents a rupture from these origins, it should come as no surprise that the criminal justice system continues to operate in a way that has not significantly departed from its earliest mandate.

In this article, I contend that the current configuration of the justice system in Canada fails to reflect the breadth of the legal and political relationship between Indigenous peoples and the Crown. This is owing at least in part to the federal government's inability to take seriously Indigenous understandings of the treaties as affirming the continuity of Indigenous peoples' legal, political, economic, spiritual, and societal practices. Rather than looking to treaties as historic events, I engage them as active relations that hold the potential to be operationalized in ways both repressive and productive; that is, they can either constrain or broaden the exercise of Indigenous law and governance depending on how they are interpreted and applied. This is a particularly urgent inquiry in the current era of recognition and reconciliation, where Indigenous visions of treaty relationships are continually expected to find their place within the existing boundaries of Western structures of law and governance despite state commitments to implement them in a more robust form. ${ }^{1}$

To demonstrate the potential ways in which treaties can offer the space to inform the reconfiguration of governmental powers relating to justice, I explore Indigenous understandings of the "peace, order and good government" clause in the numbered treaties, arguing that this clause can be understood as symbolizing the continuity of Indigenous authority over justice, among other realms of governance. I argue that Indigenous law-making authority is inherent, was affirmed in treaties, and thus that the unilateral imposition of the western criminal justice system remains a violation of treaty rights. I then offer several qualifications and cautions regarding the potential implications of Indigenous justice systems for Indigenous women. I conclude by exploring some of the ways in which treaty rights have been limited and contained by one-sided understandings of treaties and rigid notions of constitutionalism in Canada. 


\section{The "Made-in-Canada" Approach to Law and Order}

Scholars have established that the legal and political repression of Indigenous peoples has been central to the establishment and consolidation of colonial governance in a range of contexts. ${ }^{2}$ This is certainly true in Canada, where colonial authorities would need to eliminate or at least significantly minimize the legitimacy of Indigenous forms of government in order to stake out claims to power and jurisdiction. Yet, Indigenous political subordination has not remained constant across different periods in history. As many scholars have noted, early relations between Indigenous peoples and settlers can be characterized by a deeper and more mutual respect for legal pluralism. ${ }^{3}$ For instance, Lisa Ford illustrates how legal pluralism broke down across British settler states in the second quarter of the nineteenth century as settler sovereignty increasingly became associated with the "exercise of perfect territorial jurisdiction" which required the repression of Indigenous orders of law and governance. ${ }^{4}$ Additionally, civilization and assimilation programs imposed less of a fiscal burden than the costs associated with maintaining diplomatic relations with Indigenous peoples. Thus, as $\mathrm{McHugh}$ and Ford note, the recognition of Indigenous legal and social systems was gradually replaced by a vision of Canada in which "a minority of 'civilized' farming Indians would survive in the midst of a flourishing settler colonial economy." 5 These evolving dynamics contextualize the shift from Indigenous juridical independence towards legal subjecthood under the authority of Dominion governments. ${ }^{6}$

In the Canadian prairies, the settler state's early efforts to extend colonial law and jurisdiction over Indigenous peoples were largely carried out by the North West Mounted Police (NWMP). Prior to this, the Hudson's Bay Company (HBC) operated a "substantial legal system" yet interfered relatively infrequently with Indigenous peoples' existing legal and political institutions. ${ }^{7}$ The NWMP maintained favorable relations with Indigenous peoples early on; however, the North-West rebellion, the negotiation of treaties, and the implementation of the Indian
$A c t^{8}$ dramatically shifted the NWMP's efforts away from the maintenance of social stability in the prairies and towards the enforcement of policies geared towards Indigenous repression and assimilation. ${ }^{9}$

While the mandate of the NWMP has evolved over time, its primary and perhaps most distinctive function relative to the structure of the Canadian state has been to police western settlement through the application of Canadian law. As Sidney Harring has written, "[a]ny kind of military force could have asserted Canadian sovereignty in the west.... But only a federal police force could bring the Indians and Metis within the reach of Canadian law."10 This force required the exercise of extra-ordinary judicial power. Legal scholars describe the early NWMP as "a self-contained legal institution organized on a quasi-military model: Mounties arrested, prosecuted, judged, and jailed offenders under their jurisdiction." 11 This "made-in-Canada" approach to maintaining law and order, carried out in many regions by the NWMP, regarded the exercise of comprehensive and exclusive state legal authority over Indigenous peoples as integral to the particular form and operation of settler colonialism in Canada. The contours of this approach became increasingly refined as Canadian officials sought to craft new jurisprudence on Indigenous rights that was both distinct from the British Crown and that sought to formally prohibit the exercise of Indigenous legal orders under the Indian Act. ${ }^{12}$

The contemporary configurations of Canadian institutions must be contextualized and understood in light of these origins and their continuities. For they are not merely historical phenomenon but remain woven into the fabric of Canadian legal institutions that have yet to experience any significant reconfigurations of power. Over time, as the rhetoric and ideologies surrounding Canadian nation-building and Indigenous-state relations evolved, many reforms of the criminal justice system were proposed and some implemented, though none altered the reality of Indigenous legal and political subordination in a substantial way. Further, while there has been increased recognition of Aboriginal and treaty 
rights in domestic and international law, this recognition has not been accompanied by any structural changes that create space for the exercise of Indigenous law and governance relative to federal and provincial governments. Rather, constitutionally-recognized Aboriginal and treaty rights have largely been interpreted by the Canadian courts in a way that focuses narrowly on the continuity of cultural identity within the existing frame of settler sovereignty. ${ }^{13}$

Unsurprisingly, multiple inquiries into the interactions between Indigenous peoples and the criminal justice system have found that not only is the mainstream justice system not working for Indigenous peoples, it also continues to be marked by deeply rooted forms of Eurocentrism, imperialism, racism, and sexism. ${ }^{14}$ As survivors of gendered violence and families of women who have gone missing or been murdered have affirmed, the criminal justice system is one of the most significant factors that functions to perpetuate violence against Indigenous women and girls in Canada. ${ }^{15}$ State institutions not only deprive Indigenous people of justice but also operate to mask the frequent and extreme forms of violence that Indigenous people face when interacting with them. As the racist and evolutionary doctrines of civilization that justified Canada's early Indian policy have been called into question over time, the Crown has committed to offering limited degrees of change to the political relationship with Indigenous peoples, while also further concretizing its own authority and jurisdiction. ${ }^{16}$ Indeed, the settler colonial structure has demonstrated an incredible capacity to reinvent and stabilize itself in the face of Indigenous peoples' assertions of our humanity, rights, and agency.

As the foundations of mainstream justice systems find their origins in an early colonial context which unapologetically and actively repressed and criminalized Indigenous legal and political systems in the interest of asserting and guarding settler sovereignty, then it is to the foundations of this relationship we must return to address ongoing issues with the system itself. It is necessary to ask: what changes might be devised if we focus our efforts on addressing the underlying relationship of colonial subordination, rather than aiming to treat its contemporary symptoms through piecemeal initiatives? How might Indigenous peoples move towards change beyond reforms to mainstream systems, measures of cultural recognition and sensitivity, the establishment of "alternative" justice systems, and other proposals that continue to be contingent upon federal government funding, priorities, and discretion? ${ }^{17}$ What would it look like if we advocated for a move towards modes of coexistence grounded upon more just terrain, such as those that Indigenous peoples sought to create in negotiating treaties? Here we might return to the ideas of relationship that treaty First Nations consented to in the first place and think about what sort of changes might result from that important starting point.

\section{Treaties, Jurisdiction, and the Maintenance of Peace and Order}

In creating frameworks of co-existence through treaties, Indigenous peoples agreed to share the land with newcomers yet also sought to ensure the maintenance of good relations, in terms of their own pre-existing relationships and those that had yet to be established with other Indigenous peoples and settler newcomers. The numbered treaties were thus intended to ensure the continuity of traditional forms of governance while also creating new relationships that would govern Indigenous and non-Indigenous peoples. This would allow Indigenous peoples to maintain their ways of life and relations with creation while learning about new ways of life, thus permitting the beginning of new livelihoods without having to relinquish existing ones.

Treaties were intended to be renewed and revisited over time in order to ensure good relations into the future. As such, I am of the view that the role of treaty descendants is not just to interpret the meaning of these agreements and then promptly shelve them. Nor is it to acknowledge their spirit and intent yet declare them irrelevant in light of current power asymmetries. Rather, it is to work towards implementing them in ways that have relevance and importance 
today. Treaty-based modes of relating can and should offer important inspiration to inform the ways in which Indigenous peoples might seek to govern our relations with others in contemporary contexts and can offer important inspiration in thinking through the crises of justice that Indigenous peoples continue to face. Yet in doing so, it is vital that all treaty partners remain mindful of the limitations of narrow conceptions of treaty implementation that arise from onesided, transactional understandings of treaties as representing the surrender of Indigenous land and political authority. Rather, to fully engage with the possibilities that treaties hold today, it is imperative that we foreground Indigenous understandings of treaty relationships and the breadth of rights and obligations that these give rise to.

Each of the numbered treaties contains an iteration of a commitment from Indigenous peoples to maintain "peace and good order between each other, and between Indigenous peoples and newcomers." Further, the chiefs committed to assist the officers of Her Majesty in bringing to justice and punishment any Indian offending against the stipulations of the treaty, or infringing the laws in force in the country. In reviewing this clause, it is important to bear in mind that Crown assumptions of Indigenous peoples' subjecthood and the concept of land cession under treaties have now been widely discredited. ${ }^{18}$ If we look beyond the written version of treaties, it becomes possible to engage with the potential ways in which the peace and order promise symbolized far more than Eurocentric assumptions of Indigenous peoples' desire to surrender our ancestral relationships to the land in exchange for the opportunity to become servants of the Queen.

As James Youngblood Henderson observes, the peace and order clause suggests that Chiefs and Headmen "accepted the continuing responsibility to exercise the powers of maintaining peace and good order in the ceded territory and to perform certain governmental and legal duties." 19 He notes that under English legal traditions, this clause can be understood as acknowledging the authority of Indigenous
Chiefs as independent of the imperial Crown or the Dominion of Canada. Indigenous peoples' authority was not positioned as having been created or granted by the Crown, but as emanating from customary law. ${ }^{20}$ As Indigenous governance pre-dated the arrival of newcomers, treaties represented a commitment to direct this authority towards maintaining good relations in agreeing to share the land with them. Henderson's analysis is useful in elucidating the ways that the peace and order clauses both recognized the authority of the Chiefs to maintain peace and good order and placed limits on the Crown's authority in accordance with western legal principles. At the same time, there is also enormous meaning that can and should be drawn out from contemplating what this promise represents under Indigenous law. As Borrows writes, Indigenous peoples understood their responsibility to maintain peace and order as a promise made both to the Crown and to the Creator in accordance with sacred law. ${ }^{21}$ Thus, the peace and order clauses highlight the need to respect and apply Indigenous law, and not merely Indigenous administration of Canadian law, within contemporary treaty territories. ${ }^{22}$

Further, the canons of treaty construction created by the Canadian courts have also emphasized the importance of looking beyond Eurocentric readings and towards Indigenous understandings in interpreting treaties, among other principles that are intended to direct the courts' attention beyond the written version of treaties. ${ }^{23}$ Looking beyond the written records of Crown negotiators can allow us to recognize that the peace and order promises articulate a commitment to good relations in which both newcomers and Indigenous people would bear responsibilities for maintaining the operation of legal systems into the future. For instance, insights offered by the Federation of Saskatchewan Indian Nations and the Report of the Aboriginal Justice Inquiry of Manitoba indicate that the peace and order clauses affirm the inherent and ongoing jurisdiction of Indigenous peoples vis-à-vis the Canadian state. ${ }^{24}$ As treaties have been affirmed in section 35(1) of the Constitution Act, so too have the powers and liberties of Indigenous treaty partners in treaty territories. ${ }^{25}$ Yet, despite 
theoretical commitments to contemplate Indigenous understandings of treaties in the courts, these are not always followed in practice. Even when they are employed, they do not contemplate the implications of treaty relationship that arise from Indigenous legal orders. Rather, western judicial frames continue to foreclose upon the implementation of a nation-to-nation political relationship under the treaties where authority is not delegated but derived from Indigenous peoples' moral, political, and spiritual relationships to the land.

When understood as relationship frameworks rather than transactions, treaties can represent a vital source of inspiration for possible changes to the ways in which responsibilities for justice could be divided between Indigenous, federal, and provincial governments, including through the establishment of shared and separate legal systems. This position was articulated by the Royal Commission on Aboriginal peoples, which argued that the recognition and affirmation of existing Aboriginal and treaty rights in section 35(1) gives constitutional scope for Aboriginal self-government in matters relating to the establishment of justice systems. ${ }^{26}$ Thus, self-government should not be narrowly envisioned but should also encompass the jurisdiction to establish and maintain Aboriginal justice systems. While the RCAP focused generally on self-government as an Aboriginal right recognized under section 35(1), it also recommended emphasizing the role of treaties in the realization of justice for Indigenous nations, suggesting that "it is vital that the link between governance and treaties be re-established, including the right to institute Aboriginal justice systems." ${ }^{27}$

It is beyond the parameters of this article to articulate what the establishment of Indigenous justice systems would look like in individual contexts and geographies. Many existing reports and inquiries already offer such insights, and ultimately Indigenous justice systems would be most effective if designed by and in the interest of meeting the needs of those they purport to protect. The focal point here is that under the treaties, Indigenous peoples saw the division of power and retention of governing authority as central to the maintenance of just relations as they agreed to share the land with newcomers. And while the peace and order commitments can offer important grounds upon which to work towards the implementation of self-government under the treaties within contemporary contexts, this proposal should also be accompanied by several cautions that relate to the contemporary political climate.

First, it is important to be mindful that "clause-based analyses" and other efforts aimed at interpreting the substance of specific terms could have the unintended effect of reifying treaties or framing them in a static way by focusing attention on fixed terms rather than the nature of relationships that were entered into and the breadth of possible ways of enacting those relationships. It must be remembered that treaties were never intended to be fixed or locked into a static form but were to represent a framework for relationship that could be revisited and employed by future generations. While it is important to recognize that certain aspects of this relationship, such as the retention of pre-existing ways of life, and respect for legal and political plurality, were intended to be carried on in perpetuity, it is also vital that treaties not be interpreted in overly essentialist or rigid terms, as doing so would betray their purpose. Rather, there is an ongoing need for analyses that both critically deconstruct and purposefully disorient the dominant ways in which treaties have been operationalized in western law and politics in order to cultivate more expansive grounds upon which to understand them.

Second, culturally-grounded measures of law and justice and appeals to treaty-based modes of relating will not, in and of themselves, alleviate issues of patriarchy, misogyny, and heteronormativity that are now commonplace in many Indigenous communities. Owing in large part to the work of Indigenous feminists and Indigenous women, it has become clear over the past few decades that questions relating to Indigenous self-governance cannot be divorced from questions of gendered oppression. ${ }^{28}$ Understandably, these concerns have been raised in response to proposals for enhanced governing and lawmak- 
ing authority within Indigenous communities, which risk advancing the concentration of male power and privilege within communities. Thus, such dialogues must take seriously the reality that gendered and sexualized hierarchies, forms of discrimination, and violence are significant problems that need to be addressed within any initiatives geared towards the development and advancement of Indigenous justice systems.

At the same time, Indigenous patriarchy and heteronormativity should not be invoked as the rationale for the ongoing legal and political subordination of Indigenous peoples. As Napoleon, Snyder, and Borrows have noted, Indigenous peoples have significant intellectual legal resources for thinking about and challenging gendered violence..$^{29}$ Yet, appeals to egalitarian or matriarchal traditions merely cloud our ability to identify and bring forth these resources. As the above authors observe, " $[\mathrm{t}]$ here was gendered violence in Indigenous societies historically and sometimes it was very significant. The historic accounts of and responses to violence and social issues within and between communities provide Indigenous peoples with legal resources for dealing with similar issues of violence today." ${ }^{30}$

For far too long, treaty implementation has been positioned in contradistinction to the purportedly "individualist" orientation of Indigenous women's issues, as if one form of justice precludes realization of the other. Yet, why is it that gender-based violence is rarely, if ever taken up as a treaty issue? Treaties were intended for Indigenous peoples to co-exist well with European newcomers and with other Indigenous peoples. The peace and order clause affirmed that Indigenous peoples would continue to live in accordance with our own legal traditions, which direct us in maintaining good relationships with all other living beings. ${ }^{31}$ Treaty-based modes of relating are thus incredibly relevant in holding one another accountable for the myriad forms of violence that shape contemporary life, and to the maintenance of healthy interpersonal and intra/inter-group relations between Indigenous peoples ourselves.

While the expansion of Indigenous political authority and jurisdiction is necessary for any substantial reconfiguration of the justice system, I also see it as vital that Indigenous nation-building and political empowerment are accompanied by dedicated strategies geared towards affecting structural changes within Indigenous communities. Treaties were intended to be renewed and revisited over time to ensure their applicability to future generations and to help navigate new issues that might arise in the relationship. But along with their renewal also come new considerations that arise from contemporary circumstances. That is, the discourses surrounding treaty implementation today must be attentive to new issues, such as the gendered division of powers in and beyond Indigenous communities. Beyond integrating "women's perspectives" or analyses of "women's roles in treaties" into the self-government conversation, there are deep structural changes that are required to ensure that Indigenous women are playing central roles within these processes.

The peace and order commitment is only one element of the treaties that confirms the pre-existing authority of Indigenous peoples to administer and maintain justice. Further, treaties themselves represent but one of many vehicles that could create greater space for Indigenous law-making authority and other dimensions of governance relative to federal and provincial governments. With this in mind, the next section turns to some of the limitations of the ways in which treaties have been taken up in constitutional law and politics, in an effort to elucidate how the Constitution often operates for Indigenous peoples as a form of containment rather than a catalyst for change.

\section{Constituting (In)justice under Section 35(1)}

The Canadian Constitution has historically played a paradoxical role relative to the advancement of Indigenous peoples' political aspirations. On the one hand, Indigenous peoples have at times sought to influence constitutional politics to ensure the continuity and protections of our rights in the face of government efforts to eliminate them. On the other hand, we have in many 
contexts sought to resist the constitutional recognition of our rights in order to preserve and protect our own authority and nationhood as distinct from Crown orders of government. ${ }^{32}$ This latter position flows from the simple fact that Indigenous peoples' ability to govern ourselves, engage in nation-building, and maintain sustainable and generative relations with our ancestral lands and waterways pre-exists contact with newcomers and is not contingent upon constitutional recognition.

From the 1970s - 1990s, many Indigenous peoples participated heavily in efforts geared towards constitutional change, perhaps representing some of the most prominent and influential constitutional actors at the time. ${ }^{33}$ Decades later, Indigenous peoples now have the benefit of hindsight and can assess the potential of constitutional politics in light of the existing record. This allows us to engage with the theoretical possibilities for change that the Constitution might offer, while also being mindful of the ways in which the Constitution has frequently been invoked in practice to contain the possibilities for substantial change to the configuration of the relationship between Indigenous, federal, and provincial governments.

While section 35(1) has offered varying degrees of protection for select Aboriginal and treaty rights, it has also failed in many contexts to bring about the level of structural change desired by Indigenous peoples. This is not to say that section 35(1) could not be read up and interpreted in a way that results in broader affirmations of Indigenous governance, or that offers stronger degrees of protection for Indigenous rights. Such an approach would accord more closely with Indigenous understandings of treaty constitutionalism. ${ }^{34}$ Yet, as Borrows has argued, while Canada generally adopts a "living tree" tradition of constitutional interpretation, this approach is interrupted by "originalist" tendencies in constitutional interpretations of Aboriginal and treaty rights, which freezes them in the past and limits the potential for their evolution. Indeed, the "interpretive inconsistency" he observes with respect to Canada's Constitution has been evident since the entrenchment of Aboriginal and treaty rights within section 35(1) of the Constitution. ${ }^{35}$

When attempts were made to negotiate federal and provincial recognition of a right to Indigenous self-government in the years following patriation, the first ministers and premiers relentlessly deferred to the constitutional division of powers to guard against the possibility that Indigenous self-government would involve any reallocation of resources or land. While the federal government claimed to acknowledge the "inherent right to self-government" as a section 35(1) right under the 1995 Inherent Rights Policy (IRP), the IRP engaged self-government as anything but inherent; self-government was treated as delegated, contingent, and restricted in breadth and depth. ${ }^{36}$ Further, under the IRP, self-government was located "within the framework of the Canadian Constitution" as a measure that must be negotiated in such a way that would ensure a "harmonious relationship" with "federal and provincial laws." ${ }^{37}$ To exercise self-government, participating communities had to consent to their ongoing political subordination within the settler colonial structure. Employed in this way, the Constitution functioned to guard against the sharing of powers and jurisdiction between federal, provincial, and Indigenous governments. ${ }^{38}$

The continuity of Indigenous law and governance should not be interpreted as a right to self-government in a delegated, subordinate, and contingent form. Indigenous systems of governance pre-date the negotiation of treaties, finding their foundation in Indigenous peoples' legal traditions and not in the Constitution. While some might regard the recognition of existing treaty rights under section $35(1)$ as offering a measure of protection and respect for the preexisting rights of Indigenous peoples, the criteria that the courts have developed to identify an Aboriginal or treaty right drastically narrows the dimensions of treaty relationships that are able to receive Constitutional protection under section 35(1). The courts have interpreted section $35(1)$ as providing protection for those aspects of pre-contact life that were integral to the distinctive culture of an Indigenous group. ${ }^{39}$ Even 
if one ascribes to this narrow interpretation of Indigenous rights, do the laws and governance that a community has lived by for centuries not encompass formative and instrumental parts of what makes us who we are and how we live? Unfortunately, the capacity for Indigenous peoples to exercise our own laws in local matters continues to be restricted by federal, and increasingly provincial, jurisdiction. At the same time, the Constitution is selectively invoked to guard against any structural change to this configuration of power.

While the courts have not demonstrated a willingness to revisit existing constitutional arrangements in such a way that would be required to make space for Indigenous governance, ${ }^{40}$ they have revisited the constitutional division of powers in allowing the provinces to assume many of the federal government's responsibilities towards Indigenous peoples. For instance, in Grassy Narrows First Nation $v$ Ontario (Natural Resources), ${ }^{41}$ the Court acknowledged the unique constitutional relationship established with Indigenous peoples and the Crown under treaties, but adopted a "doctrine of constitutional evolution" that would allow the provinces to take up many of the Crown's responsibilities towards Indigenous peoples. ${ }^{42}$ To be clear, many Indigenous treaty partners contest the federal government's delegation of power to the provinces in areas that impact Indigenous peoples. This is not to say that the treaty relationship is static or immutable, it is certainly intended to change and transform over time. Yet in the absence of Indigenous consent, the jurisdictional powers of the provinces remain a violation of treaties in the eyes of many Indigenous peoples. While Indigenous peoples are considered to be the responsibility of Canada under section 91(24) of the Constitution, allowing the province greater jurisdiction with respect to Indigenous peoples and lands means that we find ourselves increasingly governed by entities that have no responsibility towards us.

Finally, consider the Canadian federal government's rationale for its longstanding opposition to the United Nations Declaration on the Rights of Indigenous Peoples (UNDRIP)..3 For many years, Canada withheld its support for the
UNDRIP on the grounds that it was unconstitutional, and when the federal government did adopt it, they stated that implementation would only occur within the confines of Canada's Constitution. ${ }^{4}$ Yet, the drive to domesticate the UNDRIP within the structure of the Constitution functions to minimize the potential transformations that would arise from a robust reading and application. ${ }^{45}$ With all this in mind, it becomes apparent how the sanctity of existing constitutional arrangements can be invoked selectively to pre-empt Indigenous claims to jurisdiction, and so maintain both federal and provincial powers and the legal and political subordination of Indigenous peoples.

When Indigenous peoples propose revisiting what we understand to be the unjust configurations of power in Canada, we have seen that time and time again these suggestions are rejected as unconstitutional. But what of the continued infringement of the forms of treaty constitutionalism upon which Indigenous peoples agreed to share the land? As Jim Tully writes, the negotiation of treaties established conventions of treaty constitutionalism such as consent and mutual dialogue which require that new forms of consent be obtained to affect fundamental changes in the relationship. ${ }^{46}$ Whether treaties are understood as agreements to enter into a relationship with one another or to resist incorporation within settler colonial states, both of these understandings recognize that treaties represent political frameworks that affirm Indigenous peoples' nationhood.

Although the Canadian courts have acknowledged the continuity of pre-existing Aboriginal and treaty rights under section 35(1), these efforts have increasingly focused on the continuity of cultural identity rather than the continuity of Indigenous peoples' customary law. As Mark Walters observes, in aiming to articulate a modern theory of Aboriginal and treaty rights, the courts have departed from the principle of continuity that informed historical understandings of common law Aboriginal rights. ${ }^{47}$ Historical common law principles included respect for the "separation of powers, rule of law, and fairness" which recognized local, customary laws, but was 
"not primarily concerned with preserving distinctive cultures" ${ }^{48}$ While they have sought to bring forward common law doctrines such as the principle of continuity along with the entrenchment of section 35(1), the courts have developed new doctrines of Aboriginal rights that have distorted the purpose of the principle of continuity. Importantly, Walters prompts reflection beyond the Court's culturalist criteria, and towards the consequent exclusions:

What happens to the unselected common law Aboriginal rights after 1982? Since it would be contrary to the general spirit behind the entrenchment of Aboriginal rights in 1982 to conclude that section 35(1) extinguished certain common law Aboriginal rights, it must be concluded that there remains a set of nonconstitutional Aboriginal rights at common law.... First Nations in Canada should therefore consider... where it is worth arguing that nonintegral and/or post-contact customary laws (if unextinguished) still have common law status outside the protective boundaries of section 35(1). ${ }^{49}$

In raising this question, Walters points to possible ways of thinking about Aboriginal and treaty rights that are not confined by the contours of Canadian constitutionalism, but that may exist outside of it. Alternatively, a broader reading of the Constitution could flow from an approach that looks beyond the question of which Aboriginal and treaty rights are protected under section 35(1) and interrogates the associated limits that they place upon federal and provincial authority. As Bruce Wildsmith argues, since treaty Indians "have not consented to the intrusion of non-aboriginal criminal law and criminal courts on their internal affairs...the imposition of nonaboriginal definitions of crimes and the imposition of non-aboriginal criminal processes and courts does infringe the existing treaty rights of treaty Indians and so prima facie infringes section 35(1) of the Constitution Act, 1982." ${ }^{50}$ Further, Wildsmith notes that such an infringement would not be "justifiable" under the Court's own criteria as Indigenous peoples did not consent to the imposition of non-Aboriginal law, nor is there any evidence that the imposition of the non-Aboriginal justice system is least impair- ing of rights. ${ }^{51}$ Thus, he proposes that a possible remedy to the current infringement of treaty relationships may involve a withdrawal of federal jurisdiction over Indigenous peoples in areas of governance that Indigenous peoples retained or re-affirmed through the negotiation of treaties.

As the above review illustrates, there are many ways to revisit and think beyond the Canadian Constitution to create space for more robust understandings of Indigenous governance as affirmed in treaties. Perhaps thinking beyond the forms of confinement imposed by section 35(1), for some, will simply involve living in accordance with treaty relationships as Indigenous peoples understand them, regardless of whether they enjoy constitutional recognition. For others, it might mean continually working towards making space for Indigenous orders of governance by calling for greater appreciation and respect for Indigenous laws, and for the continuity of Indigenous law-making authority under the treaties. Yet for others it may involve working to affect a shift towards the forms of treaty constitutionalism that many Indigenous peoples envisioned in negotiating treaties.

The point of this section is not to prescribe and assess the merits of every possible way of activating a broader interpretation of treaties; rather it is to demonstrate how selective and strategic interpretations of the Constitution have continually operated to place parameters around the exercise of Indigenous governance. The proper foundations, function, and exercise of Indigenous law has been suppressed in many ways through these constitutional confinements. Treaties, then, continue to play an integral role in evolving colonial logics of dispossession, finding state recognition through forms of implementation that are to occur in harmony with its existing division of jurisdiction and resources. In the process, the focus of treaty politics has continually and strategically been diverted away from outstanding questions of land theft and the legal and political subordination of Indigenous treaty partners. Hopefully, awareness of these current constitutional confinements can help treaty partners envision possibilities for new approaches to justice, be it through the renewal and reconfigu- 
ration of past governing arrangements in contemporary contexts, or by moving towards ways of life that have yet to be detailed.

\section{Conclusion}

To date, Indigenous efforts geared towards implementing shared governing and law-making authority under the numbered treaties have repeatedly come up against constitutional barriers that uphold Canada's existing configurations of power, presuming the legitimacy of Crown sovereignty but also the legitimacy of powers that have increasingly been delegated to the provinces. Far from an add-and-stir approach, which would involve the reform of mainstream justice institutions or the delegation of Indigenous authority to administer programs that continue to be controlled by federal and provincial governments, this article has called for deconstruction of the foundational structure of settler colonialism in Canada. It has argued that this structure must be revisited to address the ongoing legal and political subordination of Indigenous peoples in general, and in the realm of justice in particular. It has sought to demonstrate that Indigenous understandings of the peace and order promises in the treaties represent one of many possible sources of inspiration for a shift in the current division of authority and jurisdiction relating to the justice system. Finally, it has interrogated the Crown and the Court's narrow understanding of section 35(1), demonstrating how the Constitution is invoked and interpreted selectively and inconsistently to delimit Aboriginal and treaty rights while guarding the current configurations of settler colonialism in Canada. In light of all of this, it has been suggested that arrangements that would currently be "unconstitutional" are precisely what Indigenous peoples should strive towards as we imagine new approaches to justice.

\section{Endnotes}

* Gina Starblanket is an Assistant Professor in the Political Science Department at the University of Calgary. The author thanks Heidi Kiiwetinepinesiik Stark and Daniel Voth for helpful conversations surrounding this article.
1 For an important critique of the politics of recognition in Canada, see Glen Coulthard, Red Skin, White Masks (Minneapolis: University of Minnesota Press, 2014). For a critique of the politics of reconciliation in Canada, see Dian Million, Therapeutic Nations: Healing in an Age of Indigenous Human Rights (Tuscon: University of Arizona Press, 2013).

2 Heidi Kiiwetinepinesiik Stark, "Criminal Empire: The Making of the Savage in a Lawless Land" (2016) 19:4 Theory \& Event; Audra Simpson, "The State Is a Man: Theresa Spence, Loretta Saunders and the Gender of Settler Sovereignty" (2016) 19:4 Theory \& Event; Sidney Harring, White Man's Law: Native People in Nineteenth-Century Canadian Jurisprudence (Toronto: University of Toronto Press, 1998); Lisa Ford, Settler Sovereignty: Jurisdiction and Indigenous People in America and Australia, 1788-1836 (Harvard: Harvard University Press, 2010).

3 James Tully, Strange Multiplicity: Constitutionalism in an Age of Diversity (Cambridge: Cambridge University Press, 1995); John Borrows, Canada's Indigenous Constitution (Toronto: University of Toronto Press, 2010); Harring, White Man's Law, supra note 2.

4 Ford, Settler Sovereignty, supra note 2 at 166.

5 Paul McHugh and Lisa Ford, "Settler Sovereignty and the Shapeshifting Crown" in Lisa Ford and Tim Rowse, eds, Between Indigenous and Settler Governance (New York: Routledge, 2012) 25.

6 Ibid.

7 Harring, White Man's Law, supra note 2 at 242.

8 RSC 1985, c I-5.

9 Bill Waiser and Blair Stonechild, Loyal Till Death: Indians and the North-West Rebellion (Calgary: Fifth House, 1997).

10 Harring, White Man's Law, supra note 2 at 242.

11 Ibid at 241.

12 McHugh and Ford, "Settler Sovereignty", supra note 5 at 32.

13 Mark Walters, “The 'Golden Thread' of Continuity: Aboriginal Customs at Common Law and Under the Constitution Act, 1982" (1999) 44 McGill L J 711.

14 René Dussault and Georges Erasmus, Bridging the Cultural Divide: A Report on Aboriginal People and Criminal Justice in Canada (Ottawa: Royal Commission on Aboriginal Peoples, 1996); Paul Chartrand et al., Report of the Aboriginal Justice Inquiry of Manitoba (Winnipeg: Aboriginal Justice Implementation Commission, 1999); Frank Iacobucci, First Nations Representation on Ontario Juries: Report of the Independent Review Conducted 
by the Honourable Frank Iacobucci (Toronto: Office of the Attorney General, 2013).

15 Privy Council Office of Canada, Our Women and Girls are Sacred: Interim Report of the National Inquiry into Missing and Murdered Indigenous Women and Girls (Vancouver: Privy Council Office, 2017).

16 Consider Prime Minister Justin Trudeau's repeated calls for the renewal of a nation-tonation relationship with Indigenous peoples, which he qualifies as one "that is guided by the spirit and intent of the original treaty relationship", while not departing from previous approaches to treaty implementation in law or policy. Justin Trudeau, "Speech to the Assembly of First Nations Special General Assembly" (8 December 2015), online: <https://pm.gc.ca/eng/news/2015/12/08/ prime-minister-justin-trudeau-delivers-speechassembly-first-nations-special-chiefs $>$.

17 Ted Palys, Richelle Isaak, and Jana Nuszdorfer, Taking Indigenous Justice Seriously: Fostering a Mutually Respectful Coexistence of Aboriginal and Canadian Justice (2012), online: <http:// www.sfu.ca/ palys/PalysEtAl-2012-Aboriginal \&CanadianJustice-final. pdf $>$ at 26.

18 Dussault and Erasmus, Cultural Divide, supra note 14 at 148.

19 James Henderson, "Interpreting Sui Generis Treaties" (1997) 36 Alta L Rev 46 at 82.

20 Ibid.

21 Borrows, Indigenous Constitution, supra note 3 at 27.

$22 \quad$ Ibid at 25.

$23 R v$ Marshall, [1999] 3 SCR 456, 178 NSR (2d) 201.

24 Federation of Saskatchewan Indian Nations, Indian Treaty Rights: The Spirit and Intent of Treaty (1979) at 12; A C Hamilton and C M Sinclair, Report of the Aboriginal Justice Inquiry of Manitoba (1991) at 63.

25 Ibid.

26 Royal Commission on Aboriginal Peoples, "Bridging the Cultural Divide: A Report on Aboriginal People and Criminal Justice in Canada" (Ottawa: Minister of Supply and Services, 1996).

27 Dussault and Erasmus, Cultural Divide, supra note 14 at 69.

28 Emma LaRocque, "Re-Examining Culturally Appropriate Models in Criminal Justice Applications" in Michael Asch, ed, Aboriginal and Treaty Rights in Canada: Essays on Law, Equality, and Respect for Difference (Vancouver: UBC Press, 1997) at 75.

29 Emily Snyder, Val Napoleon, and John Borrows, "Gender and Violence: Drawing on Indigenous Legal Resources” (2015) 48 UBC L Rev 593.
30 Ibid at 596.

31 For instance, Borrows explains that the "peace and order" clause of the treaties was understood by Elders in the Cree language through the terms miyo-wicehtowin, which directs people to create and maintain good relations; pastahowin, which imposes limits on human actions and entails consequences when such limits are crossed; and wahkotowin, which conveys that "laws and duties must be followed in order to have good relationships." See John Borrows, "Indigenous Constitutionalism: Pre-Existing Legal Genealogies in Canada" in Peter Oliver, Patrick Macklem, and Nathalie Des Rosiers, eds, The Oxford Handbook of the Canadian Constitution (Oxford: Oxford University Press, 2017) 13 at 31.

32 Sharon Venne, "Treaty Indigenous Peoples and the Charlottetown Accord: The Message in the Breeze" (2011) 4 Constitutional Forum 43.

33 Joyce Green, "Balancing Strategies: Aboriginal Women and Constitutional Rights in Canada" in Joyce Green, ed, Making Space for Indigenous Feminism, 2nd ed (Winnipeg: Fernwood Publishing, 2017) 169.

34 See James Youngblood Henderson, "Empowering Treaty Federalism" (1994) 58 Sask L Rev 241; Kiera Ladner, "Treaty Federalism: An Indigenous Vision of Canadian Federalisms" in François Rocher and Miriam Smith, eds, New Trends in Canadian Federalism (Peterborough: Broadview Press, 2003) 167.

35 John Borrows, Freedom and Indigenous Constitutionalism (Toronto: University of Toronto Press, 2016) at 130, 159.

36 Specifically, the scope of political rights that could be negotiated under the IRP was to be limited "to matters that are internal to the group, integral to its distinct Aboriginal culture, and essential to its operations as a government or institution." Indian and Northern Affairs Canada, The Government of Canada's Approach to Implementation of the Inherent Right and the Negotiation of Aboriginal Self-Government (Ottawa: Government of Canada, 1995).

37 Ibid.

38 Note that there is a substantial difference between a declaration of Indigenous rights or title, and the recognition of Indigenous law as having equal or superior authority to federal or provincial law. For a discussion of this distinction see Michael McCrossan and Kiera Ladner, "Eliminating Indigenous Jurisdictions: Federalism, the Supreme Court of Canada, and Territorial Rationalities of 
Power" (2016) 49:3 Canadian Journal of Political Science 411.

$39 R v$ Van der Peet, [1996] 2 SCR 507 at 44, 23 BCLR (3d) 1 .

40 For instance, the Court indicated that "the rights of self-government encompassing a power to make general laws governing the land, resources, and people in the territory are legislative powers which cannot be awarded by the courts. Such jurisdiction is inconsistent with the Constitution Act, 1867 and its division of powers." See Delgamuukw $v$ British Columbia, [1997] 3 SCR 1010 at 34, 66 BCLR (3d) 285.

412014 SCC 48, [2014] 2 SCR 447.

42 Ibid at para 35.

43 GA Res 61/295, UN Doc A/RES/61/295 (2007) (adopted 13 September 2007).

44 In 2016, Justice Minister Jody Wilson-Raybould stated that the UNDRIP would be adopted within the confines of Canada's constitution, a prospect which is to be facilitated through the building of a "made in Canada" approach to recognizing
Indigenous rights to land and governance. See James Munson, "Ottawa Won't Adopt UNDRIP Directly into Canadian Law: Wilson-Raybould", iPolitics (12 July 2016), online: <https://ipolitics. ca/2016/07/12/ottawa-wont-adopt-undripdirectly-into-canadian-law-wilson-raybould/>.

45 The UNDRIP recognizes that Indigenous peoples have the right to self-determination and that we have the right to maintain and strengthen our distinct political, legal, economic, social, and cultural institutions, while retaining our right to participate fully, if we so choose, in the political, economic, social, and cultural life of the state.

46 Tully, Strange Multiplicity, supra note 3 at 122.

47 Walters, "Golden Thread", supra note 13 at 713.

48 Ibid at 742.

49 Ibid at 747.

50 Bruce Wildsmith, “Treaty Responsibilities: A CoRelational Model” (1992) 26 UBC L Rev 324 at 331.

51 Ibid at 332. 